\title{
Suspended Sentence in Spain: Decarceration and Recidivism
}

\author{
José Cid \\ Criminologia Aplicada a la Penologia \\ Department of Political Science and Public Law \\ Universitat Autònoma de Barcelona \\ e-mail: Josep.Cid@uab.es
}

The final, definitive version of this paper has been published in Probation Journal, 52 (2):

169-179, 2005, by SAGE Publications Ltd.

Available at http://dx.doi.org/10.1177/0264550505052686 


\begin{abstract}
The suspended sentence - along with the fine- is the most commonly used alternative to prison in Spain. This sentence is generally regarded as a good sanction because it avoids the personal and financial costs of prison for occasional offenders that are not in need of rehabilitation. The main aim of this paper is to present data and empirical research about the effectiveness of the suspended sentence with respect its two main goals: reducing the use of prison and preventing offenders from re-offending. The data appear to suggest that this is an effective sentence in these terms, but the paper also raises questions about the need to replace suspended sentences with more rehabilitative orders in some special cases.
\end{abstract}

\title{
Keywords
}

Suspended sentence, decarceration, recidivism, Spain. 


\section{Introduction}

The suspended sentence - a prison sentence that is not implemented as long as the offender refrains from committing another offence - seems to have played a very important role in the limitation of the use of prison in many jurisdictions ${ }^{i}$. However, in the punitive mood apparent in some western countries - Spain among them - the suspended sentence could be submitted to criticism for being a 'soft' sanction. In this context, it seems important to explore whether, in the light of the available evidence, this non-custodial sanction should be supported or replaced by other alternatives more matched to the seriousness of the offence and/or more aimed at the rehabilitation of the offender.

The paper begins with a brief discussion about the possible justifications of the suspended sentence in the desert and utilitarian theories of punishment. It seems that the latter theory could support suspended sentence so long as it is true that no other intervention is needed for the rehabilitation of the offender. After presenting the legal framework of the suspended sentence and showing that, in common with other countries, in Spain this sentence has produced a decarceration effect in reducing the use of prison, the paper explores the evidence about the level of recidivism of people granted suspended sentences. The data appear to be supportive of this sentence but nevertheless some further debate may be required about the need to replace it by other sentences in some particular cases.

\section{Is the suspended sentence a justifiable punishment?}

In a system of alternatives to prison based on the principles of desert (Wassik-Von Hirsch 1988:570) it seems that there is no room for the suspended sentence. If the suspended sentence is to be applied in cases of serious offences then the suspension of the prison sentence - with no other requirement for the offender than not committing another offence - would not express the censure that the crime would be seen to deserve. On the other hand, if the suspended sentenced is to be applied to non-serious offences, then there might be more appropriate non-custodial sentences - like the discharge or the fine - able to 
express the more limited censure deserved by the crime and furthermore the use of imprisonment in case of default could be inappropriate (Wassik-Von Hirsch 1988:570) ${ }^{\mathrm{ii}}$.

. For these reasons, drawing on desert theory, the English Criminal Justice Act of 1991 made the suspended sentence applicable only in exceptional cases, leading to a practical abolition of this sentence in the years that followed (Ashworth 2001:68).

From a utilitarian approach however, the suspended sentence might attract more approval. Almost a century ago the German scholar Von Liszt, and other participants in the "International Union of Criminal Law" recommended the introduction of the suspended sentence, linking this to the "occasional criminal theory". According to this theory, those offenders whose offending were occasional would refrain from re-offending merely through the threat of the prison. However, for such offenders, not in need of rehabilitation, the prison experience itself could be counterproductive, partly because of the possibility of coming under the negative influence of other more experienced inmates (Von Liszt 1882: 89-90).

An analysis of the suspended sentence from a 'cost-benefits' point of view, shows that the possible benefits of the suspended sentence - avoidance of prison experience and saving state resources - should be compared with its costs. These supposed costs might include, firstly, a weakened deterrence or moral education effect in comparison to more serious punishments and, secondly, the possibility that the level of recidivism of offenders might be higher than with other kinds of punishments more focused on incapacitation or on rehabilitation. In the discussion below these two 'costs' of the suspended sentence are considered.

The advocates of the suspended sentenced have usually watered down the first objection or 'cost' - its possibly weaker capacity for deterrence/moral education - arguing that it should only be applicable for non-serious offences in respect of which the need for deterrence or moral education is, in any case, more limited. More generally, it seems that research in the area of deterrence does not confirm a strong correlation between rising severities of punishments and subsequent levels of criminality (Von Hirsch-BottomsBurney-Wikström 1999:48).

The second objection to or 'cost' of the suspended sentence - the possibly lesser capacity to reduce the level of recidivism of offenders compared to other sanctions - 
becomes the heart of a utilitarian discussion about the effectiveness of this sentence. As stated before, there are at least theoretical grounds for suggesting that the suspended sentence might be effective in preventing recidivism so long as it effectively targeted occasional offenders that might refrain from committing new offences only due to the conviction and the threat of prison in case of a new offence.

This hypothesis is, of course, one that is amenable to research enquiry. It is possible to explore the level of recidivism of people who have received suspended sentences. If the level is very low, then it seems that the "occasional criminal theory" might be confirmed. But, once we know the level of recidivism of the people granted the suspended sentence we should make appropriate comparisons with other non-custodial sanctions ${ }^{\text {iii }}$. Only then will we be able to answer the question about the justification of the suspended sentence from a utilitarian point of view.

\section{Legal framework and use of the suspended sentence in Spain}

The research about recidivism of offenders presented below has been done with people who were granted suspended sentences in Spain. Given that each legal system can use suspended sentences in a different ways, it is worth introducing the main legal features of the suspended sentence in Spain.

The Spanish penal code distinguishes between: minor offences ("faltas") and offences ("delitos"). Minor offences are usually punished with a fine or, in some cases, judges have the discretion to impose a fine or arrest. In practice, the usual sanction for a minor offence is a fine. In the case of offences, the most common punishment is prison and only for some offences does the judge have discretion to impose a fine.

When the mandatory legal punishment for the offence is prison (for example, with offences like theft of more than $400 €$, burglary, drug trafficking and robbery) the law establishes a minimum and maximum sentence length (for example, the legal punishment for a theft is between 6 and 18 months of prison). In such cases, the judge has to impose the prison sentence and then s/he has to decide whether or not the suspended sentence might be granted.

For a suspended sentence to be granted ${ }^{\mathrm{iv}}$, the offender has to meet the following criteria: 
(i) the prison sentence should not be more than two years;

(ii) the offence should be the first offence of that person (or a relevant time has passed between his or her latest conviction and the present offence). A suspended sentenced is possible even when the judge deals with a first offence but the offender has committed another offence subsequently (prior to the court hearing);

(iii) the person has paid compensation to the victim (except when the person is unable to do so).

If the offender meets the criteria then the judge has discretion to grant a suspended sentence. In cases where the judge decides against imposing a suspended sentence, s/he has to explain the reasons for that decision.

According to previous by Cid-Larrauri and colleagues (2002), when the legal conditions are fulfilled, the suspended sentence is the most common decision. The following table shows the results of this research:

Table 1: Use of the suspended sentence by Spanish judges

\begin{tabular}{|l|l|l|}
\hline CRIMINAL RECORD OF THE OFFENDER & $\begin{array}{l}\text { SUSPENDED } \\
\text { SENTENCE }\end{array}$ & PRISON \\
\hline NO OTHER OFFENCE & $98.5 \%$ & $1.5 \%$ \\
\hline OLD OFFENCES & $55.5 \%$ & $45.5 \%$ \\
\hline POST-OFFENCES & $44 \%$ & $56 \%$ \\
\hline ALL ELIGIBLE OFFENDERS & $84.2 \%$ & $15.8 \%$ \\
\hline
\end{tabular}

Source: Cid-Larrauri and colleagues (2002:66-68). The research is a representative sample of the convictions imposed in 1998 by the judges of Barcelona, which deal with offences punishable with a maximum of three years' imprisonment.

As table 1 shows, judges tend to "automatically" grant a suspended sentenced when they sentence a first-time offender who has not committed another offence between the current offence and the decision about the suspended sentence. When the offender has an old criminal record or, after the date of the actual offence but prior to disposal, has committed other offences, then a suspended sentence is roughly granted in half of the cases.

The most relevant variable in the decision of judges is the criminal record of the offender -having a clean record is a guarantee of getting a suspended sentence-. Other 
variables that in the study of Cid-Larrauri and colleagues (2002:66-70) reached statistical significance in the decision of judges were: public prosecutor agreement with the suspended sentence, compensation to the victim, not being in prison in the moment of the decision and not being drug-addicted. All these make more probable the granting of the suspended sentence to the offender.

It is relevant to point out that judges tend to decide about suspended sentences without the help of a pre-sentence report that might give relevant information about the prediction of recidivism.

The law establishes two kinds of suspended sentence: a straight suspended sentence - in which the only obligation of the offender is to refrain from committing another offence during the time of suspension (two to five years) - and a suspended sentence with probation - in which the offender is placed under the supervision of a probation officer or has to participate in some treatment or has to refrain from some activities.

In practice, according to the research of Cid-Larrauri and colleagues (2002:67) judges disregard almost absolutely the possibility of combining the suspended sentence with probation ${ }^{\mathrm{v}}$.

The main reasons for neglecting probation are, in my opinion, the following: first, the fact that judges don't feel culturally close to the "rehabilitation ideal" which would support probation because until recently the possibility of imposing probation didn't exist in Spain; second, the fact that the introduction of probation in the penal code of 1995 was done without giving additional means to judges for sentencing (for example, judges don't have a probation officer in the court to make reports and to implement the order and they have to address for doing these duties to a very ill-founded social service of the administration).

\section{Suspended sentence and decarceration}

The penal code of 1995 made some important reforms in the system of alternatives to prison. The most important of which were: to set the upper limit for consideration of suspended sentences at two years imprisonment (instead of one year as in the previous penal code of 1973); to admit a replacement of prison sentence up to two years 
imprisonment for fine (even when the offender has criminal record) and to abolish the prison sentences less than six months, making it mandatory for the judge the replacement of this sentence for fine or weekend arrest.

One way of verifying if the new system has been effective in reducing the use of prison sentences consists of comparing the evolution of the number of convictions with the evolution of prison admissions. If no other reasons are operating, the system would be effective if, in relation to convictions, admissions into prison tend to decrease. Table 2 shows the absolute number of convictions and admissions to prison in the recent years and (taking 1996 as a basis) the relationship between these two variables.

Table 2: Convictions for offences and prisons admissions, absolute numbers and relationship between these two variables, Spain (1996-2002)

\begin{tabular}{|l|l|l|}
\hline YEARS & $\begin{array}{l}\text { N. CONVICTIONS FOR } \\
\text { OFFENCES }\end{array}$ & N. PRISONS ADMISSIONS \\
\hline 1996 & 117,097 & 51,568 \\
\hline 1997 & 118,415 & 55,739 \\
\hline 1998 & 117,498 & 53,521 \\
\hline 1999 & 109,755 & 47,598 \\
\hline 2000 & 106,775 & 41,569 \\
\hline 2001 & 110,228 & 41,359 \\
\hline 2002 & 116,345 & 41,768 \\
\hline
\end{tabular}




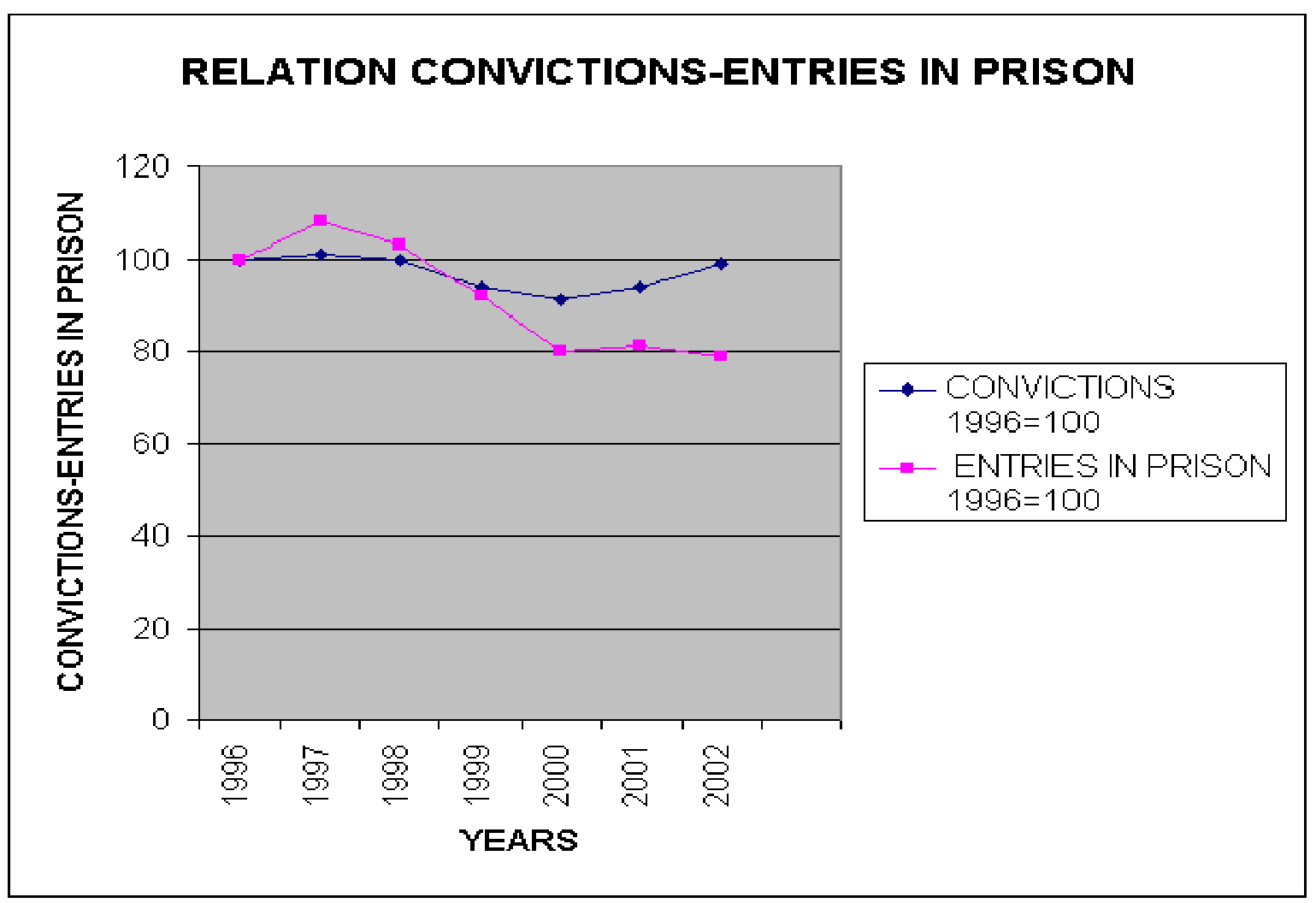

Source: INE (Spanish National Institute of Statistic, http://www.ine.es) for convictions. Data on prisons admissions are not published. The information has been provided to the author by the Spanish Home Office (Ministerio del Interior) and the Catalan Ministry of Justice (Conselleria de Justicia). The data on convictions include only convictions for offences ("delitos") not for minor offences ("faltas") and exclude some convictions dealt with in special courts.

Once we know that there is a very significant reduction in the number of admissions to prison in relation to convictions we should explore which is the most relevant factor in operation. From the three main reforms of the system of alternatives to prison of the penal code of 1995, before mentioned, we know by previous research that the possibility of replacing a prison sentence up to two years for fine to offenders with a recent criminal record has been scarcely used by judges (Cid-Larrauri and colleagues 2002:72) and although prison sentences up to six months have been abolished and this has produced an impact in the reduction of prison admissions, the effect has been not very important given that only few offences are punished with prison sentence less than six months (Cid-Larrauri and colleagues 2002:58). For these reasons, it seems that the main factor should be the fact that the penal code of 1995 has increased the upper limit of the suspended sentence up to two years imprisonment. 
The confirmation that, as it has happened in other countries, the increase in the use of the suspended sentence -due to the rise of the upper limit form one to two years imprisonment- is the main responsible for the reduction in the prison admissions comes from table 3, which shows the proportion of prison sentences which are suspended, between 1996 and 2003.

Table 3 Prison Sentences (unsuspended and suspended), Spain (1996-2003) $)^{\text {vi }}$

\begin{tabular}{|l|l|l|l|}
\hline YEAR & $\begin{array}{l}\text { TOTAL OF PRISON } \\
\text { SENTENCES }\end{array}$ & $\begin{array}{l}\text { UNSUSPENDED } \\
\text { PRISON } \\
\text { SENTENCES }\end{array}$ & $\begin{array}{l}\text { SUSPENDED } \\
\text { PRISON } \\
\text { SENTENCES }\end{array}$ \\
\hline 1996 & 66,417 & $59,646(89.8 \%)$ & $6,771(10.2 \%)$ \\
\hline 1997 & 63,276 & $56,660(89.5 \%)$ & $6,616(10.5 \%)$ \\
\hline 1998 & 43,549 & $38,943(89.4 \%)$ & $4,606(10.6 \%)$ \\
\hline 1999 & 85,663 & $75,823(88.5 \%)$ & $9,840(11.5 \%)$ \\
\hline 2000 & 58,710 & $49,800(84.8 \%)$ & $8,910(15.2 \%)$ \\
\hline 2001 & 69,661 & $55,143(79.2 \%)$ & $14,518(20.8 \%)$ \\
\hline 2002 & 68,049 & $42,791(62.9 \%)$ & $25,258(37.1 \%)$ \\
\hline 2003 & 61,708 & $34,483(55.9 \%)$ & $27,225(44.1 \%)$ \\
\hline
\end{tabular}

Source: This data is unpublished. The data has been provided to the author by the Spanish Ministry of Justice.

Table 3 means clearly that in the process of implementation of the penal code of 1995 there has been a progressive proportion of prison sentences which have been suspended and, as it has happened in other countries, it is possible to conclude that also in Spain the suspended sentence has produce a "decarceration" effect ${ }^{\mathrm{vii}}$. 


\section{Suspended sentence and recidivism}

Given that we have indicated that the suspended sentence, in conjunction with other reforms, has had a relevant effect in the reduction of prison admissions, the next question is to consider the costs of this penal sanction, measured on the basis of the recidivism of the people who have benefited from it. The lesser the level of recidivism the greater the confirmation of the "occasional offender theory", that supports the suspended sentence. Nevertheless, as stated before, the second step of the research - which has not yet been undertaken - would be comparison with the results of other non-custodial sanctions.

The research conducted in this regard in which we have just analysed the level of recidivism of a sample of people who in 1998-1999 were granted a suspended sentence by the judges of Barcelona.

The research consists of a follow-up of offenders that in a previous study (CidLarrauri and colleagues 2002) were granted a suspended sentence. This earlier research aimed at exploring the application of alternatives to prison by Spanish judges - examined the sentences imposed on 1,425 offenders. The sample was representative of the convictions imposed by the judges of Barcelona - who dealt with those offences that permitted sentences of up to three years' imprisonment - in 1998. From these 1,425 offenders, 315 got the suspended sentence.

The present research is only a modest first step that deals with one part of the 315 offenders that received a suspended sentence. From this 315 offenders, we have selected 119 , who received the suspended sentence from 10 of the 23 judges of Barcelona at this time ${ }^{\text {viii }}$. These 119 offenders received suspended sentences between April 1998 and December 1999.

We followed up of these 119 offenders by checking if, up to 31st July 2004, (roughly a five years' follow-up) they had been incarcerated in Catalan prisons. There were practical reason for taking incarceration -instead of rearrest or reconviction - as a measure of recidivism. At least in Spain this is the easier data to obtain. Additionally, taking incarceration as a measure of recidivism, could be appropriate if the goal is to target persistent offenders, because in Spain it would be very difficult for those with three or more convictions not to spend some time in prison ${ }^{\text {ix }}$.

The recidivism of the offenders is shown in the following table: 
Table 4: Recidivism rates of offenders granted the suspended sentence

\begin{tabular}{|l|l|l|}
\hline $\begin{array}{l}\text { CRIMINAL RECORD OF } \\
\text { THE OFFENDERS }\end{array}$ & INCARCERATED & NON INCARCERATED \\
\hline NO OTHER OFFENCE & $10.6 \%$ (n. 9) & $89.4 \%$ (n. 76) \\
\hline $\begin{array}{l}\text { OLD OFFENCES OR } \\
\text { POST-OFFENCES }\end{array}$ & $38.1 \%$ (n. 8) & $61.9 \%$ (n. 13) \\
\hline ALL OFFENDERS & $17.6 \%(\mathrm{n} .21)$ & $82.4 \%$ (n. 98) \\
\hline
\end{tabular}

We analysed if there were statistically significant differences between those incarcerated and those not incarcerated with respect to the following variables: a) age when committing the current offence; b) sex; c) kind of current offence; d) nationality; e) criminal record; e) financial means of the offender ${ }^{\mathrm{x}}$. The aim of these comparisons was to get more information in order to - in future research with a larger sample - do an analysis about the factors more able to predict recidivism. The results are shown in the following table: 
Table 5: Variables associated with recidivism

\begin{tabular}{|c|c|c|c|c|}
\hline \multicolumn{2}{|c|}{ VARIABLES } & INCARCERATED & NON & STATISTICAL \\
\hline \multirow[t]{2}{*}{ AGE } & UP TO 25 & $27.3 \%$ (n. 9) & $72.7 \%$ (n.24) & \multirow[t]{2}{*}{ no } \\
\hline & MORE 25 & $15 \%$ (n.12) & $85 \%$ (n.68) & \\
\hline \multirow[t]{2}{*}{ SEX } & MALE & $18.1 \%$ (n.19) & $81.9 \%(\mathrm{n} .86)$ & \multirow[t]{2}{*}{ no } \\
\hline & FEMALE & $14.3 \%$ (n. 2 ) & $85.7 \%$ (n. 12) & \\
\hline \multirow{3}{*}{$\begin{array}{l}\text { CURRENT } \\
\text { OFFENCE }\end{array}$} & ROBBERY & $66.7 \%$ (n. 2) & $33.3 \%$ (n. 1) & \multirow[t]{3}{*}{ no } \\
\hline & $\begin{array}{l}\text { DRUG } \\
\text { TRAFFIC }\end{array}$ & $33.3 \%$ (n.5) & $66.7 \%(\mathrm{n} .10)$ & \\
\hline & $\begin{array}{l}\text { NON- } \\
\text { VIOLENT } \\
\text { PROPERTY } \\
\text { OFFENCES }\end{array}$ & $18.3 \%$ (n. 11) & $81.7 \%$ (n. 49) & \\
\hline \multirow[t]{2}{*}{ NATIONALITY } & SPANISH & $18.9 \%$ (n. 20) & $81.1 \%(\mathrm{n} .86)$ & \multirow[t]{2}{*}{ no } \\
\hline & FOREIGNER & $7.7 \%$ (n. 1) & $92.3 \%$ (n. 12) & \\
\hline \multirow[t]{2}{*}{$\begin{array}{l}\text { CRIMINAL } \\
\text { RECORD }\end{array}$} & $\begin{array}{l}\text { NO OTHER } \\
\text { OFFENCE }\end{array}$ & $10.6 \%$ (n. 9) & $89.4 \%$ (n. 76) & \multirow[t]{2}{*}{ yes } \\
\hline & $\begin{array}{l}\text { OLD } \\
\text { OFFENCES OR } \\
\text { POST- } \\
\text { OFFENCES }\end{array}$ & $38.1 \%$ (n. 8 ) & $61.9 \%$ (n. 13) & \\
\hline \multirow[t]{2}{*}{ LAWYER } & \begin{tabular}{|l} 
PAID \\
LAWYER
\end{tabular} & $4.3 \%$ (n. 1) & $95.7 \%$ (n. 22) & \multirow[t]{2}{*}{ no } \\
\hline & $\begin{array}{l}\text { STATE } \\
\text { LAWYER }\end{array}$ & $20 \%$ (n. 17) & $80 \%$ (n. 68) & \\
\hline
\end{tabular}

The results of the research could be summarized as follows:

(i) When a suspended sentence is granted to offenders with only the current conviction in their criminal record, the recidivism rate - measured by incarceration - is very low $(10.6 \%)$.

(ii) When the suspended sentence is granted to offenders that - although not having recent convictions - have either old convictions or convictions for offences committed after the current offence, then the recidivism rate increases significantly up to $38.1 \%$. 
(iii) The only variable statistically correlated with recidivism is the criminal record of the offender.

(iv) Although, in common with other research (Petersilia 1997, May 1999), we found that offenders with some characteristics (for example, being less than 25 when committing the current offence, being male, having been assisted by a state lawyer) show a higher rate of recidivism, none of these differences reached statistical significance. Possibly with a larger sample some of this factors could become significant.

\section{Conclusions}

The penal code of 1995 raised the limit of consideration of suspended sentences from one to two years' imprisonment. Spanish judges appear to have continued the pattern of applying this sentence automatically when offenders do not have any other prior conviction. In consequence, suspended sentences have been a powerful device for reducing the admissions into prison in the period 1996-2003.

From its origins suspended sentence was grounded on the theory that some offenders were occasional and were not in need of rehabilitation. Similar to other research, the present study confirms that only a small number of the people convicted for the first time become recidivist ${ }^{\mathrm{xi}}$. Given that in a five-year follow-up, only $17.6 \%$ of the offenders of the sample that were granted suspended sentence were incarcerated, it seems that the suspended sentence is an inexpensive means of dealing with offenders. However, we do not know to what extent this positive outcome comes from the kind of sentence per se, as opposed to other factors. Only comparative research concerning the outcomes of other non custodial sanction can address this question.

Obviously the suspended sentence has not been effective with the $17.6 \%$ of the offenders that have been incarcerated in the follow-up period. It seems that for these offenders it might have been more useful a non-custodial sanction - like probation or treatment added to the suspended sentence - aimed at confronting their criminogenic needs or the obstacles to desistance (Farrall, 2002:220).

From this point of view it may be problematic that Spanish judges decide about the suspended sentence without the help of a pre-sentence report. Although the problems of prediction are very significant, it seems that taking into consideration some social variables 
could be helpful in order to decide between a straight suspended sentence or a suspended sentence plus probation or treatment ${ }^{\mathrm{xii}}$. Possibly, with the help of the pre-sentence report the cases in with probation is added to a suspended sentence would increase.

Acknowledgments: I thanks the Catalan Ministry of Justice for facilitating me the data on the recidivism of the people of the sample. I am also grateful to Eulalia Luque, who did the statistical task, to Beatriz Tébar and Daniel Varona, who helped me in planning the research, and to Fergus McNeill and to Elena Larrauri who made a revision of the draft paper. The research has been founded by the Spanish Ministry of Education (BJU 20012075). 


\section{References}

Ashworth, A. (2001) 'The Decline of English Sentencing and Other Stories', in Tonry, M., Frase, R. S. (eds.) Sentencing and Sanctions in Western Countries. New York: Oxford University Press, pp. 62-91.

Bottoms, A. E.(1981) 'The Suspended Sentence in England, 1967-1978', British Journal of Criminology, 4(21), pp. 1-26.

Cid, J.(forthcoming) "The Penitentiary System in Spain", to be published in Punishment and Society

Cid , J. (ed.), Larrauri, E. (ed..), Escobar, G., Lahoz, J.-López i Ferrer, M., Tébar, B., Varona, D. (2002) Jueces penales y penas en España. (Aplicación de las penas alternativas a la privación de libertad). Valencia: Tirant lo blanch.

Farral, S. (2002): Rethinking What Works with Offenders. Probation, Social Context and Desístance from Crime. Devon:Willan.

Lappi-Seppälä, T. (2001) "Sentencing and Punishment in Finland: The Decline of the Repressive Ideal", in Tonry, M., Frase, R. S. (eds.) Sentencing and Sanctions in Western Countries. New York: Oxford University Press, pp. 92-150.

Luque, M. E.-Ferrer, M., Capdevila, M. (2004) La reincidencia penitenciaria a Catalunya. Barcelona: Centre d'Estudis Jurídics i Formació Especialitzada.

May, C. (1999) Explaining Reconviction Following a Community Sentence: the Role of Social Factors. London: Home Office Research Studies

Petersilya, J.(1997) 'Probation in the United States', in Tonry, M. (ed.) Crime and justice. An annual Review of Research (22), pp. 149-200.

Roberts, J. V. and Gabor, Th. (2004) 'Living in the Shadow of Prison. Lessons from the Canadian Experience of Decarceration', British Journal of Criminology, 1 (44), pp. 92-112.

Tak, P. (2001) "Sentencing and punishment in the Netherlands", in Tonry, M., Frase, R. S. (eds.) Sentencing and Sanctions in Western Countries. New York: Oxford University Press, pp. 188-221.

Von Hirsch, A., Bottoms, A. E., Burney, E., Wikström, P-O.(1999) Criminal Deterrence and Sentence Severity. An Analysis of Recent Research. Oxford: Hart Publishing.

Von Liszt, F. (1882) Der Zweckgedanke in Strafrecht (La idea del fin en el Derecho Penal. Granada: Comares, 1995).

Wasik, M. and Von Hirsch, A. (1988) 'Non-Custodial Penalties and the Principles of Desert', 
The Criminal Law Review, september: pp. 555-572.

\title{
Wasik, M. (1994) "Sentencing Guidelines: The Problem of Conditional Sentences", Criminal Justice Ethics, Winter/Spring: pp. 50-57.
}

\author{
Weigend, Th. (2001) 'Sentencing and punishment in Germany', in Tonry, M., Frase, R. \\ S. (eds.) Sentencing and Sanctions in Western Countries. New York: Oxford \\ University Press, pp. 188-221.
}

\footnotetext{
${ }^{\mathrm{i}}$ Some western countries where the suspended sentence seems to have played an important role for reducing $\mathrm{o}$ containing the use of prison sentences are: Finland (Lappi-Sepälä 2001:113-118); The Netherlands (Tak 2001:162-163); Germany (Weigend 2001:196). Although, in England in the origins the suspended sentence did not achieve the aim of replacing the use of prison (Bottoms 1981: 26), recently the reduction of its use due to the Criminal Justice Act of 1991 has produced an increase in the use of prison (Ashworth 2001:71). In Canada a form of suspended sentence (conditional prison) introduced in 1996 has produced a significant drop in the rate of custodial sentences (Robert and Gabor 2004:100). Nevertheless, this kind of suspended sentence requires the supervision of the offender.

ii In Wassik (1994) there is a more positive view of the suspended sentence, partially grounded on the pragmatic reason that if suspended sentenced is abolished "what would replace it?" (Wassik 1994:56).

iii Comparisons between people who have been sentenced in a different way but who, in the aggregate level, do not show significant differences in the relevant aspects.

${ }^{\text {iv }}$ The present paper do not deal with a special form of a suspended sentence for drug-addicted offenders who had committed a drug-related offence. This form of suspended sentence is possible for a prison sentence not more that 3 years -5 years according to a recent reform of the Spanish penal code- and it is even possible when the offender has some previous offences. For the offender to be granted this form of suspended sentence s/he has to consent in participate in a program aimed at confronting his/her drug-addiction.

(existing in the Spanish law since 1987) which is possible for offenders with criminal record

${ }^{v}$ The suspended sentence with probation was only imposed in $6 \%$ of the cases.

${ }^{v i}$ This data includes also the cases of suspended sentence for drug-addicted offenders (see foot-note iv). However, according to the research of Cid-Larrauri and colleagues (2002), this special form of suspended sentence represents only a modest $5 \%$ of the total amount of suspensions.

vii The 15\% increase in the Spanish average prison population between 1996 (112 prisoner per 100.000 inhabitants) and 2003 (128 prisoners per 100.000 inhabitants) is basically due to the abolition of good-time remission by the penal code of 1995 . For more detailed data see Cid (forthcoming).

viii The selection of this 10 judges was made for practical reasons: with respect of the convictions of these 10 judges we have copy of the written conviction and therefore we had the name of the offender. With respect to the decisions of the other 13 judges we only had the number of the decision but not the name of offender. Nevertheless we made a statistical proof in order to confirm that this 10 judges not behave in a different way with respect to the other 13 in granting the suspended sentence. The proof confirmed that there wasn't significant differences between the two groups. If the research should be continued then it would need to take into consideration the suspended sentences granted for the 23 judges.

${ }^{\text {ix }}$ If the new convictions are for offences punishable only with prison the suspended sentence will not be possible and, as we stated before, the power of the judges to replace the prison by a fine is hardly used in practice (Cid-Larrauri and colleagues 2002:72).

${ }^{x}$ Consider, in an indirectly way, for the fact that the offender was assisted during the trial by a paid lawyer.

${ }^{x i}$ A recent research in Spain, shows that, after a five-year follow-up, only $22.6 \%$ of the first-time incarcerated have been reincarcerated (Luque-Ferrer-Capdevila 2004:101).

${ }^{x i i}$ One of the conclusions of the research conducted by May (1999) was that -for first-time offenders or with very few conviction- taking into consideration some social factors could improve the prediction of recidivism (ix, 38, 49).
} 